Journal of Community Based Environmental Engineering and Management, 2020, Vol. 4, No. 1: 31-36

\title{
DOMESTIC COMMUNAL WASTEWATER TREATMENT PLANT EVALUATION IN SINDANGRASA, BOGOR, INDONESIA
}

\author{
Purnomosutji Dyah Prinajati $^{{ }^{*}}$ \\ 1) Department of Environmental Engineering, Universitas Sahid, Indonesia
}

\begin{abstract}
The communal domestic wastewater treatment plant functions to collect and treat domestic wastewater at the source location according to the communal scale treatment capacity. The communal Wastewater Treatment Plant (WWTP) in RT (neighborhood association) 01 / RW (citizen association) 09 Sindangrasa was built in 2016 using the Anaerobic Baffled Reactor (ABR) system. This study aims to evaluate the Communal WWTP by analyzing the quality of wastewater compared to PerMenLH No. 68 of 2016, calculates the processing efficiency and analyzes the water quality of the community wells around the Communal WWTP compared to regulation of PerMenKes No.416/MENKES/PER/IX/1990. Data collection techniques using the Slovin technique in the pre-research stage, direct sampling on location and testing in an accredited laboratory. The results showed the quality of wastewater exceeds the quality standard for BOD, TSS and Total Coliform parameters, the quality of residents' well water exceeds the quality standard for parameters pH, Cr VI and Total Coliform. Communal WWTPs in RT 01/ RW 09 Sindangrasa have not been efficient in treating residents' domestic wastewater. The management of Communal WWTPs needs to be improved so that the effluent quality and processing efficiency values meet the specified regulatory standards.
\end{abstract}

Keywords: domestic wastewater, evaluation, WWTP

\section{Introduction}

Along with the increase in population, the opportunity for environmental problems also increases, especially the impact caused by the disposal of both liquid and solid waste. The results of the national statistical analysis showed that as much as $67.89 \%$ of households had access to proper sanitation, but the proportion of households that still discharged domestic wastewater into sewers/ drainage channels reached $32.11 \%$. Problems that dominate and the majority derives from household waste.

${ }^{*}$ Corresponding Author:

E-mail: iinsoekandar@gmail.com

Received: 14 February 2020

Revised: 14 March 2020

Accepted: 16 March 2020
Communal Domestic Wastewater Treatment Installation is an installation that is designed to treat domestic wastewater by processing, because bathroom wastewater discharged through pipes and sludge collected in septic tanks is not feasible to be discharged directly to water bodies or environmental media.

Sindangrasa village has a high population density and high sanitation hazard conditions for the RT (neighborhood association) 01/ RW (citizen association) 09 area in the Ciliwung River Basin, so that a good sanitation system is needed. Communal-based Wastewater Treatment Plant (WWTP) in RT 01/ RW 09 Sindangrasa was built to treat domestic wastewater in the form of feces and waste from 
the bathroom by installing house connections to the sewage treatment plant.

Water treatment is carried out centrally so that the quality of treated water is safe for the environment. After the communal WWTP on RT 01/ RW 09 has been operating for 2 years, residents have begun to feel the negative impact of the construction of domestic wastewater treatment plants in RT 01/ RW 09. Smells around the area of the processing unit appear and disturb the comfort of local residents. The existence of a communal domestic wastewater treatment plant also pollutes the clean water wells of residents which are located quite close to the treatment unit. If left unchecked and not handled, it is feared that it will interfere with the health of local residents. Ineffective treatment and inconsistent maintenance of installations are the most likely causes of these negative impacts (Chandra, 2012), so it is necessary to evaluate the communal domestic wastewater treatment plant in Sindangrasa by analyzing wastewater quality compared to the Minister of Environment and Forestry Regulation No. 68 of 2016 concerning the quality standards of domestic wastewater, calculates the treatment efficiency and conducts an analysis of the quality of the well water of residents around the processing unit in accordance with Regulation of the Minister of Health No.416/MENKES/PER/ IX/1990 to determine the effect of treatment results on the issue of contamination that occurs.

\section{Research Methodology}

This research is a descriptive method through qualitative and quantitative analysis. The study was conducted at Communal WWTP RT 01/ RW 09 Sindangrasa Sub-District, East Bogor District which has a high population density with residential areas in the Ciliwung River Basin.

The study was conducted using the Slovin technique at the pre-research stage, water sampling using the grab sampling method which was then analyzed in an accredited laboratory at the research stage in order to obtain reliable results. The percentage of pollutant allowance is calculated based on inlet and outlet quality data which will then be compared in value to determine the efficiency of the processing unit.

This study is using primary data and secondary data. Primary data were obtained from observations in the pre-study, results of testing wastewater samples at the inlet and outlet, results of testing surface water samples at receiving water bodies treated from WWTP, results of testing the quality of clean water of residents around the study site and analysis of processing efficiency data. Meanwhile, secondary data was obtained from a literature study from KSM (Group of Community) Melati as the caretaker and person in charge of communal WWTP in RT 01/ RW 09, applicable standards and regulations (Direktorat Jenderal Bina Upaya Kesehatan Kementerian Kesehatan Republik Indonesia, 2011), (Iskandar et.al, 2016), previous research, references (MetCalf \& Eddy, 2003) and journal papers with similar research topic (Dian et.al, 2016)

\section{Result and Discussion}

Physical Analysis on Unit of Communal WWTP The communal wastewater treatment plant in RT 01/ RW 09 Sindangrasa uses an anaerobic baffled reactor treatment system equipped with filters, Sindangrasa Communal WWTP capacity and $48 \mathrm{KK}$ beneficiaries. The Melati KSM management structure responsible for maintaining the communal WWTP consists of 6 people. The survey was conducted on the surrounding residents and management, maintenance carried out at the communal WWTP for 2 years of operation that is checking the control basin so that no material is clogged and mud drainage has never been carried out and monitoring the quality of treated wastewater entering the receiving water body. The evaluation of the Communal WWTP unit was 
compared with the requirements of Minister of Public Works and Public Housing Regulation No. 04/PRT/M/2017 concerning the implementation of domestic wastewater management systems and it was found that there was a mismatch of unit designs at the primary treatment stage. Physical analysis is carried out on each processing unit as described in the table below.

Table 1. Physical Analysis Results of WWTP Units

\begin{tabular}{|c|c|c|}
\hline No & $\begin{array}{c}\text { Treatment } \\
\text { Unit }\end{array}$ & Physical Analysis \\
\hline 1. & $\begin{array}{l}\text { Control } \\
\text { basin }\end{array}$ & $\begin{array}{l}\text { The flow of wastewater is } \\
\text { low. There are fabric and } \\
\text { plastic waste found in the } \\
\text { basin, which prevents flow } \\
\text { to the inlet. }\end{array}$ \\
\hline 2. & $\begin{array}{l}\text { Collector } \\
\text { basin/ Inlet }\end{array}$ & $\begin{array}{l}\text { The basin are filled with } \\
\text { feces that are quite dense on } \\
\text { the surface of the water. }\end{array}$ \\
\hline 3. & $\begin{array}{l}\text { Settling } \\
\text { pond }\end{array}$ & $\begin{array}{l}\text { The removal process does } \\
\text { not function properly } \\
\text { because there is plastic waste } \\
\text { and tetrapack apart from the } \\
\text { solid stool which is finer in } \\
\text { size compared to the stool in } \\
\text { the collecting basin above } \\
\text { the water surface. } \\
\text { Wastewater then flows into } \\
\text { the pond by gravity. }\end{array}$ \\
\hline 4. & $\begin{array}{l}\text { Anaerobic } \\
\text { Baffled } \\
\text { Reactor }\end{array}$ & $\begin{array}{l}\text { The water in the pool is } \\
\text { black, foamy, there is fine } \\
\text { stool mud, there are } 2 \text { rooms } \\
\text { equipped with wasp nest } \\
\text { filter media and anaerobic } \\
\text { process occurs in this unit, } \\
\text { and } 1 \text { room before the outlet } \\
\text { basin that is not equipped } \\
\text { with filters serves as a } \\
\text { further solid separator. }\end{array}$ \\
\hline 5. & Outlet pond & $\begin{array}{l}\text { There is no mud in this pool, } \\
\text { the wastewater is black but } \\
\text { without suspended } \\
\text { particulate. }\end{array}$ \\
\hline
\end{tabular}

Analysis of Communal WWTP Wastewater Quality

All wastewater that is treated at communal WWTP is wastewater generated from domestic activities, namely toilet activities such as urination and washing hand. Characteristics of wastewater entering the installation unit contain BOD, COD, TSS, oil \& fat, ammonia and total Coliform which tends to be moderate after compared with the characteristics of domestic wastewater in general. The results of the wastewater analysis compared with the domestic wastewater quality standard according to the Minister of Environment and Forestry Regulation No.68 Year 2016 shows the quality of wastewater at the communal WWTP inlet of KSM Melati Sindangrasa Village exceeds the quality standard except the ammonia and oil-fat parameters. The quality of wastewater at the Communal WWTP WWTP Melati Sindangrasa Village also exceeds the threshold values for BOD, TSS and Total Coliform parameters. The TSS content that exceeds the quality standards at the communal WWTP outlet flows into the drainage and will affect the penetration of light so that it interferes with photosynthesis (Susanti et.al, 2018). The decrease in TSS content was influenced by the length of time the wastewater contacted with microorganisms contained in the WWTP compartment (Wulandari, 2012). The longer the contact time the TSS reduction efficiency will increase (Susanti et.al, 2018). High levels of BOD at communal WWTP outlets are caused by the high content of organic materials entering the WWTP system. The high total coliform in effluents can be due to the deposition of fecal sludge at the outlet bath. The high total coliform discharged into the environment can cause problems for public health.

Table 2 shows the result of wastewater laboratorium analysis according to the regulated parameters of sampling points of the wastewater treatment plant. 
Table 2. Results of Wastewater Quality Laboratory Analysis

\begin{tabular}{llcccccc}
\hline \multirow{2}{*}{ No } & \multirow{2}{*}{ Parameter } & Unit & \multicolumn{3}{c}{ Analysis Result } & \multirow{2}{*}{ Standard } & \multirow{2}{*}{ Analysis Method } \\
\cline { 5 - 6 } & & - & 7.2 & 6.9 & 6.5 & $6-9$ & SNI 06-6989.11-2004 \\
\hline 1 & $\mathrm{pH}$ & $\mathrm{mg} / \mathrm{L}$ & 60.00 & 42.00 & 34.80 & 30 & SNI 6989.72:2009 \\
\hline 2 & $\mathrm{BOD}$ & $\mathrm{mg} / \mathrm{L}$ & 119.28 & 82.14 & 72.45 & 100 & SNI 06-6989.15-2004 \\
\hline 3 & $\mathrm{COD}$ & $\mathrm{mg} / \mathrm{L}$ & 148.90 & 59.30 & 35.50 & 30 & SNI 06-6989.26-2005 \\
\hline 4 & TSS & 3.50 & 1.40 & 0.40 & 5 & SNI 06-6989.10-2004 \\
\hline 5 & $\begin{array}{l}\text { Minyak } \& \\
\text { Lemak }\end{array}$ & $\mathrm{mg} / \mathrm{L}$ & 7.04 & 4.92 & 4.50 & 10 & SNI 06-6989.30-2005 \\
\hline 6 & Amoniak & $\mathrm{mg} / \mathrm{L}$ & 7.04 & $1 \times 10^{5}$ & $6 \times 10^{4}$ & 3000 & APHA \\
\hline 7 & $\begin{array}{l}\text { Total } \\
\text { Coliform }\end{array}$ & $\begin{array}{c}\mathrm{MPN} / \\
100 \mathrm{~mL}\end{array}$ & $4 \times 10^{5}$ & & & & \\
\hline
\end{tabular}

Surface Water Quality Analysis at Receiving Water Bodies

Data on the results of surface water quality testing on receiving water bodies after Communal WWTP Melati Sindangrasa showed that $83 \%$ of testing parameters met quality standards in accordance with Government Regulation of the Republic of Indonesia (PPRI) No.82 of 2001. Parameters exceeding the quality standard for BOD parameters were $34.80 \mathrm{mg} / \mathrm{L}$, TSS at $35.50 \mathrm{mg} / \mathrm{L}$ and Total Coliform at $6 \times 10^{4}$ MPN/100 mL.

\section{Efficiency of Communal WWTP}

Percentage of pollutant removal did not reach the criteria set in the communal WWTP Manual that is $80 \%$ for overall processing results, according to regulation of PerMenPUPR No. 04 Year 2017, the efficiency value was calculated for TSS, BOD and COD pollutant parameters. The percentage of total allowance for suspended solids (TSS) is $76.16 \%$, COD allowance is $39.26 \%$, and BOD removal is $42 \%$. Based on these results, the Communal WWTP KSM Melati has not been efficient in treating domestic waste from residents.
Analysis of Clean Water Quality of Residents Around the Communal WWTP

The issue of contamination that occurs to the well water of RT 01 / RW 09 residents whose homes are located around the communal WWTP area is the basis for conducting laboratory testing of clean water samples from the complainant and several houses that are randomly sampled according to distance and conditions in applicable standards.

The results of tests on the quality of community well water that is suspected to be polluted (ASWC) and the quality of community well water (ASW) which are both in the area of \pm 200 meters from the location of the Communal WWTP Melati Sindangrasa, obtained two parameters that exceed the quality standards in well water polluted residents namely odor and $\mathrm{Cr}$ VI parameters in addition to the $\mathrm{pH}$ and Total Coliform content showed concentrations close to the quality standard according to the Minister of Health Regulation (PerMenKes) No.416 of 1990. While the analysis on samples of other residents' well water showed all parameters met the quality standard standard. Physically, residents' well water suspected to be polluted. It feels slimy which can be caused by high $\mathrm{pH}$ of water. 
Table 3. Results of Analysis of of Community Well Water Quality Located Around the WWTP

\begin{tabular}{|c|c|c|c|c|c|}
\hline \multirow{2}{*}{ No } & \multirow{2}{*}{ Parameter } & \multirow{2}{*}{ Unit } & \multicolumn{2}{|c|}{ Analysis Result } & \multirow{2}{*}{$\begin{array}{c}\text { Standard of } \\
\text { PerMenKes } \\
\text { No.416:1990 }\end{array}$} \\
\hline & & & ASWC & ASW & \\
\hline 1 & TDS & - & 87.00 & 106.00 & 1000 \\
\hline 2 & Temperature (onsite) & ${ }^{0} \mathrm{C}$ & 28 & 27.80 & $22-28$ \\
\hline 3 & Color & TCU & $<4.773$ & $<4.773$ & 15 \\
\hline 4 & Arsen (As) & $\mathrm{mg} / \mathrm{L}$ & $<0.0020$ & $<0.0020$ & 0.05 \\
\hline 5 & Selenium $(\mathrm{Se})$ & $\mathrm{mg} / \mathrm{L}$ & $<0.0238$ & $<0.0238$ & 0.01 \\
\hline 6 & Iron $(\mathrm{Fe})$ & $\mathrm{mg} / \mathrm{L}$ & $<0.0238$ & $<0.0177$ & 1 \\
\hline 7 & Fluoride $(\mathrm{F})$ & $\mathrm{mg} / \mathrm{L}$ & $<0.0177$ & $<0.0177$ & 1.5 \\
\hline 8 & Cadmium $(\mathrm{Cd})$ & $\mathrm{mg} / \mathrm{L}$ & $<0.0087$ & $<0.0087$ & 0.005 \\
\hline 9 & Hardness $\left(\mathrm{CaCO}_{3}\right)$ & $\mathrm{mg} / \mathrm{L}$ & $<0.0087$ & 81.03 & 500 \\
\hline 10 & Chloride $(\mathrm{Cl})$ & $\mathrm{mg} / \mathrm{L}$ & 56.72 & 18.27 & 600 \\
\hline 11 & Chromium VI (Cr VI) & $\mathrm{mg} / \mathrm{L}$ & 18.03 & $<0.005$ & 0.05 \\
\hline 12 & Manganese (Mn) & $\mathrm{mg} / \mathrm{L}$ & $<0.005$ & 0.027 & 0.5 \\
\hline 13 & $\mathrm{pH}$ (onsite) & - & 8.6 & 7.2 & $6.5-9.0$ \\
\hline 14 & Zinc (Zn) & $\mathrm{mg} / \mathrm{L}$ & 0.029 & $<0.0456$ & 15 \\
\hline 15 & Sulphate $\left(\mathrm{SO}_{4}\right)$ & $\mathrm{mg} / \mathrm{L}$ & $<0.0456$ & $<1.349$ & 400 \\
\hline 16 & Lead $(\mathrm{Pb})$ & $\mathrm{mg} / \mathrm{L}$ & $<0.0591$ & $<0.0591$ & 0.05 \\
\hline 17 & Detergent (MBAS) & $\mathrm{mg} / \mathrm{L}$ & $<0.0591$ & $<0.0591$ & 0.5 \\
\hline 18 & Total Colifom (MPN) & $\begin{array}{l}\text { MPN/100 } \\
\mathrm{mL}\end{array}$ & 46 & 8.4 & 50 \\
\hline 19 & Odor & $\mathrm{mg} / \mathrm{L}$ & Fishy & Odorless & Odorless \\
\hline 20 & Taste & $\mathrm{mg} / \mathrm{L}$ & Tasteless & Tasteless & Tasteless \\
\hline 21 & Nitrate, as $\mathrm{N}$ & $\mathrm{mg} / \mathrm{L}$ & 6.50 & 2.60 & 10 \\
\hline 22 & Nitrite, as $\mathrm{N}$ & $\mathrm{mg} / \mathrm{L}$ & 0.063 & 0.007 & 1 \\
\hline 23 & Cyanide $(\mathrm{CN})$ & $\mathrm{mg} / \mathrm{L}$ & $<0.0005$ & $<0.0005$ & 0.1 \\
\hline 24 & $\begin{array}{l}\text { Organic matter } \\
\left(\mathrm{KMNO}_{4}\right)\end{array}$ & $\mathrm{mg} / \mathrm{L}$ & 1.44 & 0.96 & 10 \\
\hline
\end{tabular}

\section{Conclusion}

\section{Evaluation}

1. The quality of treated wastewater at the Communal WWTP based on laboratory test results shows that BOD value of $60.00 \mathrm{mg} / \mathrm{L}$, COD value of $119.28 \mathrm{mg} / \mathrm{L}$, TSS value of $148.90 \mathrm{mg} / \mathrm{L}$ and Total Coliform of $4 \times 10^{5} \mathrm{MPN} /$ $100 \mathrm{~mL}$.

2. Treated wastewater quality exceeds the quality standard for BOD parameters of 34.80 $\mathrm{mg} / \mathrm{L}$, TSS of $35.50 \mathrm{mg} / \mathrm{L}$ and Total Coliform of $6 \times 10^{4} \mathrm{MPN} / 100 \mathrm{~mL}$.

3. Evaluation of the performance of Communal WWTP as a whole shows a low and insignificant efficiency condition with the percentage reduction in total suspended solids (TSS) of $76.16 \%$, COD reduction of $39.26 \%$, and reduction of BOD by $42 \%$. The percentage of BOD and COD allowance is not in accordance with the PerMenPUPR standard criteria No.04 of 2017. The expected efficiency value is based on the Sindangrasa Communal WWTP work plan manual which is $80 \%$ for the overall processing results.

\section{Recommendation}

1. Solid waste that is discharged through sewerage can inhibit the performance of WWTP so it is necessary to add screen and a grease trap unit to separate oil from water. In channels that 
have been equipped with grease trap units, regular and scheduled cleaning must be carried out by management and residents. The addition of the bar screen unit to the Communal WWTP is needed so that the processing process runs well and accordingly.

2. It is necessary to regularly drain the mud that crusts on the inlet and the settler unit.

3. A backwash system needs to be added to the Anaerobic Baffled Reactor treatment unit so that the sludge does not accumulate and causes excess nutrients.

4. It is necessary to conduct socialization and provide understanding back to the residents so as not to throw garbage in the bathroom or toilet channels as well as increase understanding of the functions of Communal WWTP, duties and responsibilities as a user.

5. There needs to be an improvement in the management of the Sindangrasa Communal WWTP located in RT 01/ RW 09 so that the management and residents actively maintain the installation buildings that have been provided by the government as an effort to improve environmental health and hygiene.

6. Further assessment needs to be carried out on the design of each Communal WWTP unit so that the test results at the outlet tub meet the quality standards and are safely disposed of in the environment.

\section{References}

Chandra B. 2012. Pengantar Kesehatan Lingkungan. Jakarta: Penerbit Buku Kedokteran EGC

Dian, G., Herumurti, W. 2016. Evaluasi Kinerja Instalasi Pengolahan Lumpur Tinja (IPLT) Keputih. Surabaya: Institut Teknologi Sepuluh Nopember

Direktorat Jenderal Bina Upaya Kesehatan Kementerian Kesehatan Republik
Indonesia. 2011. Pedoman Teknis Instalasi Pengolah Air Limbah dengan Sistem Biofilter Anaerob Aerob Pada Fasilitas Pelayanan Kesehatan. Jakarta

Iskandar, S., Fransisca, I., Ruslan, A.. 2016. Sistem Pengelolaan Air Limbah Domestik Terpusat Skala Permukiman. Jakarta: Kementerian Pekerjaan Umum dan Perumahan Rakyat

MetCalf, Eddy. 2003.Wastewater Engineering: Treatment, Disposal and Reuse, 4th ed. McGraw Hill Book Co. New York

Peraturan Menteri Kesehatan No. 416/Men.Kes/PER/IX/1990 tentang

Baku Mutu Air Bersih

Peraturan Menteri Lingkungan Hidup dan Kehutanan No. 68 Tahun 2016 tentang Air Limbah Domestik

Peraturan Menteri Pekerjaan Umum dan Perumahan Rakyat No.04/PRT/M/2017 tentang Penyelenggaraan Sistem Air Limbah Domestik

Peraturan Pemerintah Republik Indonesia No. 82 Tahun 2001 tentang Pengelolaan Kualitas Air dan Pengendalian Pencemaran Air

Susanti, D., Suprihatin, Purwanto, Y. 2018. Evaluasi Pengolahan Air Limbah Domestik dengan IPAL Komunal di Kota Bogor. Bogor: Institut Pertanian Bogor

Undang - Undang No.1 Tahun 2011 tentang Perumahan dan Permukiman

Wulandari, D. 2012. Evaluasi Desain Instalasi Pengolahan Air Limbah Kantor Pusat Pertamina. Depok: Universitas Indonesia 